\title{
TMAP Wadden Sea Vegetation Database
}

\author{
Martin Stock
}

\begin{abstract}
Vegetation changes in the salt marshes of the Schleswig-Holstein Wadden Sea National Park are measured annually since 1991 in relation to sea level rise, vegetation changes and salt marsh management. In total 249 permanent plots were established along transects with a concentration to three different locations along the coast, namely the Hamburger Hallig, the salt marshes of Westerhever and on the island of Trischen. Annually the vegetation composition and the cover of the species is measured using the LONDO scale. The measurements are part of the Trilateral Monitoring and Assesment Programm (TMAP) within the trilateral Wadden Sea Cooperation. The data provide a baseline for further studies of salt marsh succession in relation to marsh management and coastal protection activities. This report describes the available content in the TMAP Wadden Sea Vegetation Database (GIVD ID EUDE-033).
\end{abstract}

Keywords: conservation management; NATURA 2000; salt marsh; succession.

\section{TMAP Wadden Sea Vegetation Database}

Scope: Database of measurements of vegetation relevés along transects in the salt marshes of Schleswig-Holstein in relation to sea level rise and management regimes. In total, 249 permanent plots are monitored annually since 1992.

Status: completed and continuing

Period: 1992-2011

Database manager(s): Martin Stock (martin.stock@lkn.landsh.de)

Owner: LKN-SH

Dr. Martin Stock

Nationalparkverwaltung

Schlossgarten 1

25832 Tönning

Web address: [NA]

Availability: according to a specific agreement

Database format(s): Excel

Publication: [NA]

Plot type(s): time series

Non-overlapping plots: 249

Total plot observations: 249

Online upload: no

Export format(s): Excel, CSV file, plain text file

Countries: DE: $10.0 \%$

Forest: $0 \%$ - Non-forest: aquatic: 0\%; semi-aquatic: $0 \%$; arctic-alpine: $0 \%$; natural: $0 \%$; semi-natural: $0 \%$; anthropogenic: $0 \%$

Guilds: all vascular plants: $100 \%$

Environmental data: altitude: $100 \%$; other soil attributes: $100 \%$

Performance measure(s): cover: $100 \%$; other: $80 \%$

Geographic localisation: GPS coordinates (precision $25 \mathrm{~m}$ or less): 100\%

Sampling periods: [NA]

Information as of 2012-07-12; further details and future updates available from http://www.givd.info/ID/EU-DE-033

Martin Stock (martin.stock@lkn.landsh.de)

Umweltbeobachtung und Planungsgrundlagen, Nationalparkverwaltung, Schlossgarten 1, 25832 Tönning, GERMANY 